\title{
Karakteristik Proses \\ dan Karakteristik Metrik pada Keadilan Prosedural yang Dimoderasi Oleh Ketidakpastian Tugas dan Toleransi Ambiguitas
}

\author{
Ewing Yuvisa Ibrani \& Farah Nurani Qorny \\ Universitas Sultan Ageng Tirtayasa-Serang \\ Jalan Raya Jakarta KM.04 Pakupatan Serang \\ e-mail: ewing_ibrani@yahoo.com
}

Yenny Dwi Handayani

STIE Bina Bangsa - Serang

Jl. Bayangkara 47 Kota Serang

Email:yennydwih@yahoo.co.id

\begin{abstract}
This research investigates how performance evaluation procedures associated with managerial perception of procedural justice. Two metrics and two process characteristics of performance evaluation are examined. Formality of performance evaluation and voice are characterized as process characteristics, while preferred use of effort measures to outcome measures, and diversity of performance evaluation are characterized as metric characteristics. Those, are moderated by task uncertainty and tolerance for ambiguity as cores of uncertainty management theory.

Survey method is used in this research, and so purposive sampling to test 77 samples that consistof middle managers from Bantenprovince lower and middle level of firms. The result of this research proved that all four performance evaluation characteristics are not directly associated with procedural justice, yet their effect depends on the extent of perceived task uncertainty and tolerance for ambiguity of managers. In addition, voice, as process characteristics, seems to have the strongest effect of all that may leads to the increased of fairness. These findings explain some inconsistencies in previous studies on justice perception of performance evaluation procedures.
\end{abstract}

Keywords: Procedural justice, Formality, Voice, Outcome measures, Diversity, Task uncertainty, Tolerance for ambiguity.

\section{PENDAHULUAN}

Konsep tentang keadilan telah menjadi bahasan yang luas dan lazim dalam penelitian akademik (Hartmann dan Slapnicar, 2012). Landy (1978) berpendapat bahwa persepsi keadilan yang dirasakan dalam outcome dari organisasi cenderung berbasiskan proses penentuannya, misalnya, bagaimana evaluasi kinerja dilakukan dan bagaimana keputusan tentang penentuan salary dibuat. Konsep tentang proses bagaimana keputusan dibuat dapat membentuk suatu dasar yang disebut dengan keadilan prosedural (Thibault dan Walker, 1975).

Literatur organisasi menyajikan bukti yang kuat bahwa anggota organisasi dapat membentuk persepsi keadilan tentang prosedur organisasi, dan persepsi tersebut menjelaskan hasil yang penting di tempat kerja, seperti motivasi, komitmen, dan kinerja. Hal ini menunjukkan pentingnya memahami asal-usul keadilan pro-

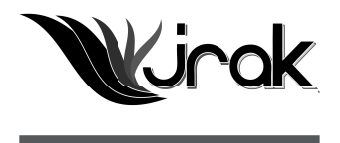

Jurnal Reviu Akuntansi dan Keuangan ISSN: 2088-0685 Vol.3 No. 1, April 2013 Pp 349-362 
Karakteristik

Proses....

sedural (Hartmann dan Slapnicar, 2012). Namun demikian, terlepas bahwa evaluasi kinerja merupakan proses yang paling rel evan dari keadilan organisasiyang mengarah pada persepsi keadilan (Folger dan Konovsky, 1989), pengetahuan tentang karakteristik yang dapat membuat evaluasi kinerja dapat dirasakan adil masih terbatas (Hartmann dan Slapnicar, 2012).

Terdapat beberapa prinsip-prinsip normatif tentang keadilan prosedural, diantaranya konsistensidan akurasi (Leventhal, 1976). Namun, keduanya bukan merupakan karakteristik yang observable atau designable dalam evaluasi kinerja (Hartmann dan Slapnicar, 2012). Oleh karena itu, meskipun atasanyang berprilaku konsisten dan akurat cenderung terlihat lebih adil dalam memberikan evaluasi kinerja, perilaku atau prosedur sebenarnya yang harus dilakukan atasan untuk meningkatkan konsistensi, akurasi, dan untuk mencapai keadilan belum banyak diketahui (Folger dan Greenberg, 1985).

Hartmann dan Slapnicar (2012) sebelumnya telah mengembangkan dan menguji teori berbasis prediksi dari efek keadilan dengan menggunakan empat karakteristik evaluasi kinerja, yaitu dua karakteristik proses dan dua karakteristik metrik, yang tergantung pada dua variabel kontekstual. Berkaitan dengan karakteristik proses, Hartmann dan Slapnicar (2012) menganalisis efek dari formalitaspada proses evaluasi kinerja (Moers, 2005), dan dampak suarakaryawan (Shields dan Shields, 1998).

Untuk karakteristik metrik, penekanan atasan pada evaluasi berdasarkan outcomemetrics dibandingkan effort metrics (E isenhardt, 1985) dan keragaman dari metrik kinerja yang dipertimbangkan oleh atasan (Ittner et al., 2003) juga dieksplorasi. Adapun dua variabel kontekstual yang dimaksud adalah: (a) ketidakpastian tugas, yang mencerminkan kompleksitas tugas yang dilakukan ol eh seorang manajer (Hartmann, 2000); dan (b) toleransi terhadap ambiguitas, yaitu karakter yang mencerminkan kebutuhan seseorang terhadap informasi yang tidak ambigu dalam situasi yang tidak pasti (Hartmann, 2005). Keduanya merupakan bagian dari konsep ketidakpastian manajemen yang menjel askanpenilai an keadi lan karyawan karena kebutuhan untuk mengatasi ketidakpastian dalam lingkungan fisik dan sosial mereka (Lind dan Bos, 2002). Hal ini mengimplikasikan bahwa persepsi keadilan dari proses evaluasi kinerja tidak dipengaruhi langsung oleh karakteristik evaluasi kinerja, tetapi lebi $\mathrm{h}$ tergantung pada persepsi ketidakpastian karyawan (Hartmann dan Slapnicar, 2012).

Penelitian ini mencoba menginvestigasi kembali efek dari empat el emen persepsi keadilan, dan bagaimana efek tersebut akan dimoderasi oleh peranan ketidakpastian tugas dan toleransi terhadap ambiguitas, sebagaimana yang sebelumnya telah dikembangkan dan diuji oleh Hartmann dan Slapnicar (2012), dalam konteks perusahaan di Indonesia.

\section{PENGEMBANGAN HIPOTESIS}

\section{Hubungan Formalitas dan Ketidakpastian Tugas terhadap Keadilan Prosedural}

Berdasarkan teori ketidakpastian manajemen, diperkirakan pengaruh positif formal itasterhadap persepsi keadilanhanya berlaku untuk tingkat ketidakpastian tugasyang lebih rendah (Hartmann dan Slapnicar, 2012). Diekmann et al. (2004) menyatakan tingkat ketidakpastian yang tinggi dari prosedur pekerjaandapat memperkuat hubungan antara keadilan proseduraldan kepuasan kerja. Namun demikian, dalam prosedur evaluasi kinerja, ketidakpastian tugas yang tinggi dapat membuat target yang telah ditetapkan, jelas dan objektif menjadi kurang terkendali dan rel evan (Hartmann, 2005). J ika manajer harus bertanggung jawab atas isuisu yang tak terkendali karena adanya ketidakpastian, mereka akan merasa evaIuasi terhadap mereka tidak memadai dan tidak adil (Choudhury, 1986). Hal ini mengakibatkan evaluasi formal menjadi problematis, sehingga metode evaluasi 
non-formal akan dipandang lebih adil (Hartmann, 2005; Lau dan Moser, 2008). Uraian tersebut mengarah pada hipotesis berikut:

$\mathrm{H}$ la. Hubungan antara formalitas dan keadilan prosedural adalah positif untuk manajer dengan ketidakpastian tugas rendah.

\section{Hubungan Formalitas dan Toleransi terhadap Ambiguitas terhadap Keadilan Prosedural}

Manajer dengan tingkat toleransi terhadap ambiguitas rendah cenderung berusaha untuk melakukan reduksi ambiguitas, yang tercermin dari pilihan mereka untuk menggunakan directive style dalam evaluasi (Marginson dan Ogden, 2005). Reduksi ambiguitas akan lebih tinggi untuk manajer dengan tingkat toleransi terhadap ambiguitas yang rendah, karena mereka memiliki preferensi yang lebih tinggi akan ketegasan dan kejelasan sebagai feedback dari evaluasi formal yang dilakukan. Sebaliknya, manajer dengan tingkat toleransi terhadap ambiguitas tinggi tidak memerlukan dan bahkan tidak menyukai adanya reduksi ambiguitas (N orton, 1975; Hartmann, 2005). Hal ini mengimplikasikan bahwa efek formalitas pada keadilan prosedural hanya lazim untuk manajer dengan tol eransi terhadap ambiguitas lebih rendah (De Cremer dan Sedikides, 2004). Oleh karena itu disimpulkan hipotesis:

H lb. Hubungan antara formalitas dan keadilan prosedural adalah positif untuk manajer dengan toleransi terhadap ambiguitasyang rendah.

\section{Hubungan Voice danK etidakpastian Tugas terhadapKeadilanProsedural}

Terbatasnya jumlah studi mengenai interaksi antara voice dan dan ketidakpastianmenunjukkan bahwa voice telah menjadi karakteristik prosesyang lebih menonjol dalam penilaian keadilan, dan pengaruh voice terhadap keadilan proseduralakan menjadi lebih positif ketika ketidakpastian kontekstualmeningkat (De Cremer dan Sedikides, 2004). Sebagaimana teori ketidakpastian manajemen memprediksi bahwa voice meningkatkan persepsi pengendalian, dan bahwa manajer dengan tingkat ketidakpastian tugas tinggi memiliki kepentingan atas pengendalian tersebut, maka diasumsikan efek positif dari voice pada keadilan sangat penting bagi manajer dengan ketidakpastian tugas tinggi (DeCremer dan Sedikides, 2004). Uraian di atas mengarah pada hipotesis:

H2a. Hubungan positif antara voice dan keadilan prosedural lebih kuat untuk manajer dengan ketidakpastian tugas tinggi dibandingkan manajer dengan ketidakpastian tugas rendah.

\section{Hubungan Voice dan Toleransi terhadap Ambiguitas terhadap Keadilan Prosedural}

Menurut Hartmann (2005), manajer yang memiliki toleransi terhadap ambiguitasrendahmenujukkan kebutuhan yang lebih tinggi untukmengamankan diri dari standar kinerja yang harus dihadapi. De Cremer dan Sedikides (2004) menemukan efek moderasi rasa ketidakpastian seseorang tentang keanggotaan organisasi mereka terhadap keadilan prosedural. Menurutnya, setiap individu pasti memiliki self-uncertainty, yaitu motivasi untuk mengurangi ketidakpastian di lingkungan mereka, dan perasaan tersebut dapat mempengaruhi respon afektif, kognitif dan perilaku mereka dalam situasi sosial yang kompleks dan dinamis. Ketidakpastian dalam self-motivates itu sendiri dapat meningkatkan sensitivitas terhadap informasi mengenai keadilan prosedural, sebagaimana informasi tersebut memiliki potensi untuk mengurangi ketidakpastian. Oleh karena itu disimpulkan hipotesis:

H2b. Hubungan positif antara voice dan keadilan prosedural lebih kuat untuk manajer dengan toleransi terhadap ambiguitas rendah dibandingkan manajer dengan toleransi terhadap ambiguitas yang tinggi . 
Karakteristik

Proses....

352

\section{Pengaruh Outcome Measures dan Ketidakpastian Tugas terhadap Keadilan Prosedural}

Evaluasi berdasarkan outcomecenderung dirasakan adil jika outcometersebut merupakan estimator usaha yang tidak bias, sehingga outcome dapat menggambarkan tingkat usaha secara akurat (Hartmann dan Slapnicar, 2012). Ouchi (1979) menyatakan bahwa bias akan terjadi pada tingkat ketidakpastian tugasyang lebih tinggi, yaitu tingkat task programmability yang rendahdi lingkungan kerja (Eisenhardt, 1985). Ketika ketidakpastian tugasmeningkat, outcome measures akan mencerminkan tingkat usaha karyawan dengan kurang akurat karena mereka cenderung untuk memasukkan gangguanyang disebabkan ol eh lingkungan pekerjaan (Merchant, 1989). Hartmann dan Slapnicar (2012) menyatakan bahwa tingginya tingkat ketidakpastian tugas dapat meningkatkan permintaan akan evaIuasi kinerja berbasiskan usaha.Uraian di atas mengarah pada hipotesis:

$\mathrm{H} 3 \mathrm{a}$. Outcome measures berpengaruh negatif terhadap keadilan prosedural untuk manajer dengan ketidakpastian tugas yang tinggi.

\section{Pengaruh Outcome Measures dan Toleransi terhadap Ambiguitas terhadap Keadilan Prosedural}

Output measures biasanya dapat diukur dan dijel askan dengan lebih objektif dibandingkan effort measures. Oleh karena itu, outcome measures dapat mengurangi ambiguitas dan bias yang dirasakan dalam proses evaluasi (Hartmann, 2005). Evaluasi terhadap usaha, memang tidak dapat dijelaskan secara akurat, sehingga memungkinkan atasan untuk mempertimbangkan perubahan sepanjang waktu yang mungkin mempengaruhi pencapaian output (Hartmann dan Slapnicar, 2012). Meskipun hal tersebut dapat mengurangi bias, namun ambiguitas pada lingkungan evaluasi dapat meningkat dan mengurangi konsistensi yang diharapkan. Hartmann (2005) menemukan bahwa manajer dengan toleransi terhadap ambiguitas yang rendah lebih sensitif terhadap efek-efek tersebut dibandingkan dengan manajer dengan toleransi terhadap ambiguitas tinggi. Manajer dengan toleransi terhadap ambiguitas tinggi relatif tidak tertarik terhadap pilihan tentang outcome atau effort measures, karena mereka tidak peduli usaha atasan untuk mengurangi ambiguitas (Hartmann dan Slapnicar, 2012). Oleh karena itu disimpulkan hipotesis berikut:

$\mathrm{H} 3$ b. Outcome measures ber pengaruh positif terhadap keadilan prosedural untuk manajer dengan toleransi terhadap ambiguitas yang rendah.

\section{Pengaruh Diversity dan Ketidakpastian Tugasterhadap Keadilan Prosedural}

Sebuah prinsip dasar dalam eval uasi kinerja adalah ketika tingkat ketidakpastian tugastinggi, maka indikator kinerja tunggal tidak dapat secara akurat mencerminkan kinerja bawahan (Hartmann dan Slapnicar, 2012). Landy (1989) menyatakan bahwa manajer yang dihadapkan dengan situasi ketidakpastian tugastinggi, akan tidak setuju dengan penggunaan indikator kinerja yang terbatas. Dengan demikian, keragaman ukuran kinerja diperlukan untuk mencerminkan secara komprehensif usaha manajer dengan ketidakpastian tugastinggi dibandingkan dengan ketidakpastian tugasrendah (Hartmann dan Slapnicar, 2012). $\mathrm{Hal}$ ini menunjukkan bahwa diversity akan meningkatkan keadilan khususnya di tingkat ketidakpastian tugasyang tinggi . U raian di atas mengarah pada hipotesis:

$\mathrm{H} 4 \mathrm{a}$. Diversity berpengaruh positif terhadap keadilan prosedural untuk manajer dengan ketidakpastian tugasyang tinggi.

\section{Hubungan Diversity dan Toleransi terhadap Ambiguitas terhadap Keadilan Prosedural}

Budner (1962) mengidentifikasi dua cara utama di mana individu dengan toleransi terhadap ambiguitasyang rendahdapat mengurangi ambiguitas yang me- 
reka alami. Pertama, mereka dapat menolak ambi guitas dengan memilih informasi hitam-putihyang dapat menyembunyikan ambiguitas (MacDonald, 1970). Kedua, mereka dapat memiliki kecenderungan untuk mengumpulkan informasi lebih tentang situasi yang mereka anggap ambigu (Budner, 1962). Oleh karena itu, manajer dengan toleransi terhadap ambiguitasrendahmungkin di satu sisi mempertimbangkan diverse metric sebagai kurang adil, karena adanya preferensi gambaran kinerja yang hitam-putih (Hartmann, 2005). Di sisi lain, diversity dapat memperluas informasi, seperti yang dicari oleh manajer dengan toleransi terhadap ambiguitasrendah. Dengan demikian, diusulkan hipotesis:

H4b. Hubungan antara diversity dan keadilan prosedural tidak di pengaruhi ol eh toleransi terhadap ambiguitas.

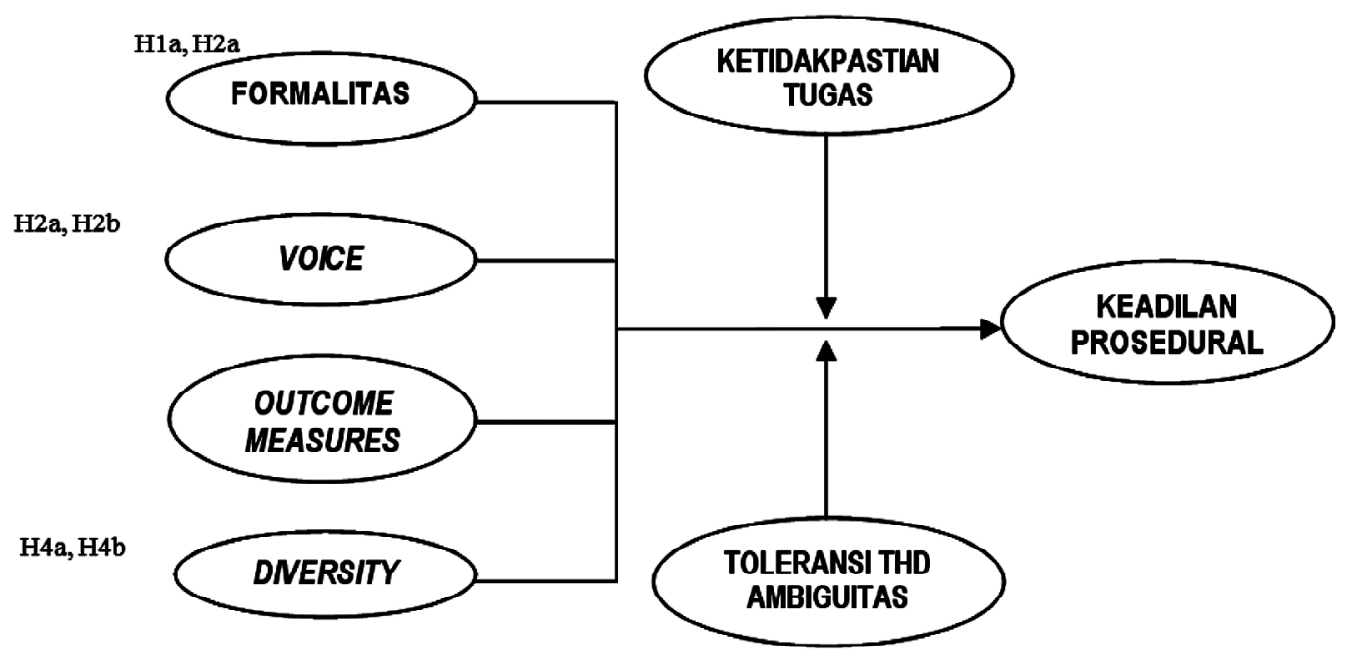

Gambar 1 Model Penelitian Sumber: Hartmann dan Slapnicar (2012)

\section{METODE}

\section{Populasi dan Sampel}

Populasi dalam penelitian ini adalah middlemanagementyang ada di perusahaan manufaktur skala kecil dan menengah di Provinsi Banten. Teknik penarikan sampel yang digunakan adalah purposive sampling, dengan kriteria utama: (1) middlemanagementperusahaan manufaktur skala kecil dan menengah di Provinsi Banten dengan jumlah karyawan minimal 100 orang; dan (2) middlemanagement yang memiliki pengalaman bekerja minimal 2 tahun.

\section{Pengukuran Variabel}

Instrumen-instrumen pengukuran yang digunakan dalam penelitian ini telah dikembangkan dan diuji ol eh peneliti terhadulu, yang masing-masing diukur dengan menggunakan skala Likert dengan lima kategori yaitu: (1) sangat tidak setuju; (2) tidak setuju; (3) netral; (4) setuju; dan (5) sangat setuju.

Formal itas dalam evaluasi kinerja (FORM) menunjukkan tingkat formalitas yang dirasakan dalam pengukuran kinerja dan penentuan reward, dan seberapa banyak objektivitas yang digunakan dalam proses evaluasi kinerja.Formalitas diukur dengan tiga item indikator yang diadopsi dari penelitian Hartmann dan Slapnicar (2012).Voice (VOICE) diukurdengan menggunakan tiga item indikator yang menunjukkan sejauh mana manajer diperbolehkan untuk mempengaruhi penentuan tujuan, dan aktif menyuarakan pendapat dalam eval uasi kinerja.Voice diukur dengantiga item indikator yang diadopsi dari penelitian Hartmann dan Slapnicar (2012). 
Karakteristik Proses....

354
Tabel 1:

Ringkasan jumlah pengiriman dan pengembalian kuesioner
Variabel outcome measures (OUT) menunjukkan sejauh mana manajer merasakan bahwa sistem evaluasi dan reward menggunakan pengukuran effortbased, bukan outcome-based. Outcome measures diukur dengandua item indikator yang diadopsi dari penelitian Hartmann dan Slapnicar (2012). Diversity (DIVERS) dal am pengukuran kinerja diukur dengan empat item indikator yang merefleksikan jumlah dimensi kinerja yang digunakan dalam evaluasi kinerja.Adapun keadilan prosedural (KPROS) diukur dengan tiga item indikator yang diadopsi dari penelitian Hartmann dan Slapnicar (2012).Keadilan prosedural mencerminkan persepsi keadilan tentang kebijakan dan prosedur yang digunakan untuk membuat keputusan.

Ketidakpastian tugas (KT) diukur dengan sembilan item indikator yang diadopsi dari penelitian Withey et. al (1983), yang di dalamnya mengekspresikan task analyzability dan task diversity sebagai dimensi dari ketidakpastian tugas. Tingkat ketidakpastian tinggi atau rendah dapat diidentifikasi melalui jawaban responden pada kuesioner. J awaban kuesioner seluruh responden dianal isis, untuk kemudian dibagi menjadi sub-grup yang memiliki ketidakpastian tugas tinggi dan rendah.

Toleransi terhadap ambiguitas (TA) diukur dengan instrumen MacDonald (1970), dimana responden diminta untuk memberikan pernyataan atas beberapa situasiambigu. Terdapat 13 item indikator untuk mengukur TA. Sejalan dengan pengukuran ketidakpastian tugas, berdasarkan analisis terhadap jawaban kuesioner, sampel kemudian dibagi menjadi sub-grup yang memiliki toleransi terhadap ambiguitas yang tinggi dan rendah.

\section{Metode Analisis Data}

Pengujian hipotesis dilakukan dengan menggunakan Partial Least Square (PLS) versi 2.0. Dengan menggunakan PLS, maka measurement dan structural model dapat diuji.Measurement modeldigunakan untuk mengevaluasi validitas dan reliabilitas instrumen.Val iditas dievaluasi dengan menguji validitas konvergen dan validitas diskriminan dari masing-masing indikator. Sedangkan realibilitas dalam PLS diuji dengan mengevaluasi cronbach's al phadan composite reliability. Cronbach's al phamengukur batas bawah nilai reliabilitas suatu konstruk sedangkan composite reliability mengukur nilai sesungguhnya reliabilitas suatu konstruk. Namun di dalam PLS, composite reliabilitydinilai lebih baik dalam mengestimasi konsistensi internal suatu konstruk (Werts et al .,1974).Structural model digunakan untuk menguji hipotesis dengan menggunakan fungsi bootstrapping.Signifikansi dapat dinilai dengan membandingkan nilai t-statisticdengan t-table, sedangkan arah hubungan (positif atau negatif) dapat dilihat dari original sample.

\section{HASIL DAN PEMBAHASAN}

\section{Statistik Deskriptif}

Kuesioner yang sudah di isi kemudian diambil sesuai waktu yang sebelumnya tel ah disepakati. Adapun waktu yang diperlukan untuk mengumpulkan data adaIah selama 2 bulan, Ringkasan jumlah pengiriman dan pengembalian kuesioner dal am penelitian ini dapat dilihat pada Tabel 1 .

\begin{tabular}{clcc}
\hline No. & \multicolumn{1}{c}{ Keterangan } & Jumlah & Persentase \\
\hline 1 & Kuesioner yang disebar & 112 & $100 \%$ \\
2 & Kuesioner yang kembali & 77 & $68,75 \%$ \\
3 & Kuesioner yang tidak kembali & 35 & $31,25 \%$ \\
4 & Kuesioner yang bisa diolah & 77 & $68,75 \%$ \\
\hline
\end{tabular}




\section{Pengujian Asumsi dan Kelayakan Model Penelitian}

Hasil dari measurement model dilaporkan pada Tabel 2-4. Untuk pengujian estimasi measurement model dan measurement model quality, dapat dinilai melalui statistikparsialuntuk reliabilitas dan validitas konstruk refleksif dalam penelitian ini (Bagozzi, 1994). Untuk uji validitas, dapat dinilai dari convergent validity, yaitu nilai average variance extracted (AVE) masing-masing konstruk dimana nilainya harus lebih besar dari 0,5 (Ghozali, 2006). Cara lain yaitu dengan membandingkan nilai square root of average variance extracted ( $\sqrt{A V E}$ ) setiap konstruk dengan korelasi antara konstruk dengan konstruk lainnya dalam model. J ika nilai ( $\sqrt{A V E}$ ) setiap konstruk lebih besar dari pada nilai korelasi antara konstruk dengan konstruk lainnya dalam model, maka dikatakan memiliki nilai discriminant validity yang baik (Ghozali; 2006).Uji reliabilitas dinilai dari composite reliability. Suatu data dikatakan reliablejika composite reliability $\geq 0,70$ (Ghozali; 2006). Dari tabel 2 dapat dilihat setiap konstruk atau variabel laten tersebut memiliki nilai compositereliability diatas 0,7 yang menandakan bahwa internal consistency dari variabel eksogen dan variabel endogennya memiliki reliabilitas yang baik.

\begin{tabular}{lcccc}
\hline & Original sampel & Sample mean & Standard error & T statistics \\
\hline FORM $1 \leftarrow$ FORM & & & & \\
FORM $2 \leftarrow$ FORM & 0.749 & 0.731 & 0.099 & 7.53 \\
FORM $3 \leftarrow$ FORM & 0.760 & 0.756 & 0.118 & 6.43 \\
VOICE1 $\leftarrow$ VOICE & 0.867 & 0.869 & 0.021 & 40.03 \\
VOICE2 $\leftarrow$ VOICE & & & & \\
VOICE3 $\leftarrow$ VOICE & 0.704 & 0.696 & 0.081 & 8.59 \\
OUT1 $\leftarrow$ OUT & 0.857 & 0.816 & 0.190 & 4.50 \\
OUT2 $\leftarrow$ OUT & 0.702 & 0.667 & 0.146 & 2.84 \\
DIVERS1 $\leftarrow$ DIVERS & 0.767 & 0.767 & 0.051 & 15.01 \\
DIVERS2 $\leftarrow$ DIVERS & 0.812 & 0.814 & 0.064 & 12.55 \\
DIVERS3 $\leftarrow$ DIVERS & 0.705 & 0.693 & 0.063 & 11.08 \\
DIVERS4 $\leftarrow$ DIVERS & 0.609 & 0.599 & 0.096 & 6.29 \\
KPROS1 $\leftarrow$ KPROS & 0.815 & 0.811 & 0.04 & 18.81 \\
KPROS2 $\leftarrow$ KPROS & 0.770 & 0.768 & 0.056 & 13.71 \\
KPROS3 $\leftarrow$ KPROS & 0.827 & 0.828 & 0.024 & 33.75 \\
\hline
\end{tabular}

C atatan: Untuk tujuan peringkasan, hasil measurement model disajikan hanya untuk kategori full sample. Parameter measurement model dan kualitas kriteria seluruhnya ada pada tingkat yang dapat diterima untuk setiap subsample dalam analisis.

\begin{tabular}{lcccc}
\hline & AVE & Composite reliability $(\boldsymbol{\rho})$ & $\mathbf{R}^{\mathbf{2}}$ & Redundancy $\left(\mathbf{Q}^{2}\right)$ \\
\hline FORM & 0.570 & 0.726 & & \\
VOICE & 0.624 & 0.766 & & \\
OUT & 0.613 & 0.759 & & \\
DIVERS & 0.529 & 0.816 & 0.837 & 0.102 \\
KPROS & 0.647 & 0.846 & 0.837 \\
\hline
\end{tabular}

\begin{tabular}{lccccc}
\hline & DIVERS & FORM & KPROS & OUT & VOICE \\
\hline DIVERS & $\mathbf{0 . 7 2 7}$ & & & & \\
FORM & 0.535 & $\mathbf{0 . 7 5 4}$ & & & \\
KPROS & 0.650 & 0.537 & $\mathbf{0 . 8 0 4}$ & & \\
OUT & 0.113 & 0.133 & 0.230 & $\mathbf{0 . 8 7 1}$ & \\
VOICE & 0.618 & 0.540 & 0.906 & 0.193 & $\mathbf{0 . 7 8 9}$ \\
\hline
\end{tabular}

C atatan: Elemen diagonal (cetak tebal) merupakan nilai square root of the variance antara konstruk dan indikatornya (AVE ). Elemen off-diagonal adalah nilai korelasi antar konstruk. Untuk discriminant validity, elemen diagonal harus bernilai lebih besar dibandingkan dengan elemen off-diagonal.
Tabel 2:

Measurement Model (Full sample, $\mathrm{N}=77$ )

Tabel 3:

Quality Criteria (Full sample, $\mathrm{N}=77$ )

Tabel 4:

Correlation matrix and discriminant validity coeficients (full sample) 
Karakteristik Proses....

356

Tabel 5:

Structural model untuk sub-grup

ketidakpastian tugas tinggi

Tabel 6 :

Structural model

untuk sub-grup

ketidakpastian tugas rendah
Tabel 5 dan 6 merupakan intisari dari nilai path estimation.Penilaian signifikansi dari estimasi parameter dinilai dari prosedur bootstrap.Predictivevalidity dari estimasi parameter di nilai melal ui cross-validated redundancy index atau yang juga disebut Stone-Geisser Q2test. J ika Q² untuk seluruh konstruk laten adalah lebih besar daripada 0, maka dapat dikatakan bahwa model penelitian memiliki predictive relevance yang cukup baik. Meskipun model dalam PLS tidak memberikan goodness of fit statistics, Vandenbosch (1996) berargumen bahwa selain reliabilitas dan validitas dari konstruk, signifikansi dari varian yang dijelaskan dan nilai $Q^{2}$ yang positif untuk keseluruhan konstruk juga dapat memberikan bukti yang cukup untuk model fit (lihat Tabel 3).

\section{Pengujian dan Pembahasan Hipotesis H la dan H $\mathbf{1 b}$}

Hasil pengujian Hipotesis $\mathrm{H}$ la menyatakan hubungan antara formalitas adalah positif dan signifikan terhadap keadilan prosedural pada sub-grup manajer dengan ketidakpastian tugas rendah. Argumen tersebut didukung dengan nilai original sample sebesar 0.204 dan t-statistik 2.20 (lihat Tabel 6), sehingga dapat disimpulkan Hipotesis $\mathrm{H}$ la diterima. Temuan ini sesuai dengan penelitian Hartmann (2005) serta Hartmann dan Slapnicar (2012).

Hipotesis $\mathrm{H} 1 \mathrm{~b}$ yang menyatakan hubungan positif formalitas pada tingkat toleransi terhadap ambiguitas rendah tidak dapat diterima. Hasil perolehan original sample adalah -0,011 dengan nilai t-statistik 0.068 (lihat Tabel 8). Temuan ini mendukung hasil penelitian yang di lakukan oleh Hartmann dan Slapnicar (2012). Saat proses evaluasi kinerja, manajer dengan tingkat toleransi ambiguitas yang rendah cenderung ber usaha untuk melakukan reduksi ambiguitas, sebagaimana mereka memiliki preferensi yang tinggi atas kejelasan dan ketegasan yang didapat sebagai feedback dari evaluasi formal. Namun dalam hal ini, reduksi ambiguitas bisa saja tidak signifikan dapat meningkatkan keadilan prosedural. Artinya, persepsi keadilan yang diharapkan dapat meningkat saat evaluasi formal dilakukan, kemungkinan besar belum dapat dirasakan ol eh manajer dengan toleransi ambiguitas rendah secara kesel uruhan. Sebaliknya, permintaan terhadap evaluasi nonformal bisa saja meningkat, karena dianggap dapat memperbaiki kelemahan dalam sistem formal, yang dapat meningkatkan akurasi (misalnya: Lau dan Moser, 2008). Manajer dengan toler ansi ambiguitas rendah bisa saja mengharapkan adanya komunikasi atau interaksi sosial yang lebih banyak pada saat evaluasi kinerja, yang akan didapat jika evaluasi non-formal dilakukan.

\begin{tabular}{lcccc}
\hline \multirow{2}{*}{ Path } & \multicolumn{4}{c}{ Sub-grup ketidakpastian tugas tinggi, $\mathbf{N}=\mathbf{4 5}$} \\
\cline { 2 - 5 } & Original sample & sample mean & S.E & T statistics \\
\hline H1a: FORM $\rightarrow$ KPROS & 0.139 & 0.134 & 0.141 & 0.98 \\
H2a: VOICE $\rightarrow$ KPROS & 0.255 & 0.297 & 0.101 & 2.20 \\
H3a: OUT $\rightarrow$ KPROS & -0.259 & -0.187 & 0.115 & 2.25 \\
H4a: DIVERS $\rightarrow$ KPROS & -0.144 & -0.205 & 0.125 & 1.14 \\
\hline
\end{tabular}

\begin{tabular}{lcccc}
\hline \multirow{2}{*}{ Path } & \multicolumn{4}{c}{ Sub-grup Ketidakpastian tugas rendah, $\mathbf{N}=\mathbf{3 2}$} \\
\cline { 2 - 5 } & Original sample & sample mean & S.E & T statistics \\
\hline H1a: FORM $\rightarrow$ KPROS & 0.204 & 0.189 & 0.092 & 2.20 \\
H2a: VOICE $\rightarrow$ KPROS & -0.214 & -0.109 & 0.207 & 1.03 \\
H3a: OUT $\rightarrow$ KPROS & 0.064 & 0.057 & 0.065 & 0.99 \\
H4a: DIVERS $\rightarrow$ KPROS & 0.108 & 0.063 & 0.118 & 0.91 \\
\hline
\end{tabular}


Hipotesis H2a menyatakan bahwa efek voice terhadap persepsi keadilan adalah lebih kuat untuk manajer dengan tingkat ketidakpastian tugas tinggi .Pengujian hipotesis menunjukkan bahwa original samplepada sub-grup ketidakpastian tinggi memiliki nilai lebih besar dan berada di tingkat signifikasi yang cukup dibandingkan pada sub-grup ketidakpastian tugas rendah (original sample0.255, tstat 2.20>-0.214, t-stat 1.03) (lihat Tabel $5 \& 6$ ). Maka dapat disimpulkan bahwa $\mathrm{H} 2 \mathrm{a}$ diterima. Temuan ini konsisten dengan hasil penelitian DeCremer dan Sedikides (2004) serta Hartmann dan Slapnicar (2012).

Sehubungan dengan toleransi terhadap ambiguitas, $\mathrm{H} 2 \mathrm{~b}$ menyatakan bahwa voice dapat lebih kuat mempengaruhi persepsi keadilan pada tingkat toleransi terhadap ambiguitas rendah. H asil H 2b menunjukkan nilai original sample-0.078 dengan t-statistik 0.452, sehingga dapat disimpulkan bahwa $\mathrm{H} 2 \mathrm{~b}$ ditolak. Namun, hasil penelitian ini menunjukkan bahwa voice mempengaruhi persepsi keadilan pada tingkat toleransi terhadap ambiguitas tinggi, yang ditdukung dengan nilai original sample 0.265 dan t-statistik 4.46 (lihat Tabel 8).

Hasil penelitian ini mendukung penelitian sebelumnya yang dilakukan ol ehH artmann dan Slapnicar (2012) yang mel aporkan hubungan yang lemah dan tidak signifikan antara voice dan keadilan prosedural di tingkat toleransi ambiguitas yang rendah. Namun demikian, penelitian ini tidak konsisten dengan penelitian yang dilakukan oleh De Cremer dan Sedikides (2004). Perbedaan hasil ini disebabkan karena penelitian yang dilakukan ol eh DeCremer dan Sedikides (2004) terfokus pada studi eksperimen terhadap beberapa undergraduated students (mahasiswa yang belum lulus), sedangkan target responden pada penelitian ini adalah middle managers perusahaan manufaktur di Banten yang terdiri dari berbagai latar belakang pendidikan, budaya, serta tingkat pengalaman yang pada akhirnya dapat mengarah pada hasil penelitian yang berbeda.

Terlepas dari perbedaan argumen tersebut, J aballa et.al (2009) menemukan fakta bahwa individu yang memiliki toleransi ambigutas yang tinggi cenderung menggunakan tingkat kreativitas yang tinggi dalam melakukan pekerjaannya dan kemungkinan besar tertarik pada resiko dan sensasi. Oleh karena itu, kebutuhan mereka untuk menyampaikan pendapat dan suara pada saat evaluasi kinerja akan meningkat, sehingga diharapkan persepsi keadilan akan dapat dirasakan bagi mereka yang memiliki toleransi tinggi terhadap ambiguitas.

\section{Pengujian dan Pembahasan Hipotesis H 3 a dan H $\mathbf{3 b}$}

Untuk $\mathrm{H} 3 \mathrm{a}$, sesuai dengan formula yang sebelumnya diprediksi, outcome measures terbukti berpengaruh negatif terhadap keadilan prosedural di tingkat ketidakpastian tugas yang tinggi.Nilai perolehan original sampeladalah sebesar 0.259 dengan t-statistik sebesar 2.25, sehingga dapat disimpulkan bahwa $\mathrm{H} 3 \mathrm{a}$ diterima.Hasil penelitian ini mendukung penelitian sebelumnya yang dilakukan oleh Ouchi (1979) dan Merchant (1989).

Hi potesis H3b menyatakan bahwa outcome measuresber pengaruh positif terhadap keadilan prosedural pada tingkat toleransi terhadap ambiguitasrendah. Nilai original sampel adalahsebesar -0.037dengan t-statistik sebesar 0.581(lihat Tabel 7), sehingga dapat disimpulkan bahwa H3b ditolak.Temuan ini mendukung penelitian sebelumnya yang dilakukan ol eh Hartmann dan Slapnicar (2012) yang melaporkan pengaruh yang lemah dan tidak signifikan antara outcome measures dan keadilan prosedural di tingkat toleransi ambiguitas rendah. Namun demikian, dalam penelitian ini, outcome measures berpengaruh negatif dan signifikan terhadap keadilan prosedural pada tingkat toleransi terhadap ambiguitas yang tinggi, yang didukung dengan perol ehan nilai original sampel sebesar -0.135 dan t-statistik 1.98 (lihat Tabel 8).

Berikut adalah penjelasan logis yang dapat disimpulkan. Outcome measures biasanya dapat diukur dan dijelaskan dengan lebih objektif, dan dianggap dapat 
Karakteristik Proses....

358

mengurangi ambiguitas dan bias yang dirasakan dalam proses evaluasi kinerja. Namun demikian, ambiguitas pada lingkungan evaluasi dapat meningkat dan mengurangi konsistensi yang diharapkan (misalnya: Hartmann, 2005). Sebagaimana individu dengan toleransi tinggi terhadap ambiguitas memiliki kepribadian yang menarik, yaitu kreatif, menyukai sensasi dan pekerjaan yang penuh dengan resiko, maka kemungkinan besar mer eka peduli dengan gaya evaluasi apakah yang akan mereka dapatkan, apakah berdasarkan usaha (effort), atau berdasarkan hasil (outcome). Ketika evaluasi kinerja yang dilaksanakan adalah berbasiskan pada usaha, maka hal tersebut diharapkan dapat mengurangi tingkat ambiguitas tinggi yang dirasakan, sehingga persepsi mereka terhadap keadilan prosedural pun akan meningkat.

Tabel 7:

Structural model untuk sub-grup toleransi terhadap ambiguitas tinggi

Tabel 8:

Structural model untuk sub-grup toleransi terhadap ambiguitas rendah

\begin{tabular}{lcccc}
\hline \multirow{2}{*}{ Path } & \multicolumn{3}{c}{ Grup toleransi terhadap ambiguitas tinggi, $\mathbf{N}=\mathbf{4 0}$} \\
\cline { 2 - 5 } & Original sample & sample mean & S.E & T statistics \\
\hline H1b: FORM $\rightarrow$ KPROS & 0.167 & 0.187 & 0.109 & 1.52 \\
H2b: VOICE $\rightarrow$ KPROS & 0.265 & 0.260 & 0.059 & 4.46 \\
H3b: OUT $\rightarrow$ KPROS & -0.135 & -0.143 & 0.068 & 1.98 \\
H4b: DIVERS $\rightarrow$ KPROS & -0.169 & -0.084 & 0.083 & 1.27 \\
\hline
\end{tabular}

\begin{tabular}{lcccc}
\hline \multirow{2}{*}{ Path } & \multicolumn{3}{c}{ Grup toleransi terhadap ambiguitas rendah, N = 37 } \\
\cline { 2 - 5 } & Original sample & sample mean & S.E & T statistics \\
\hline H1b: FORM $\rightarrow$ KPROS & -0.011 & -0.028 & 0.162 & 0.068 \\
H2b: VOICE $\rightarrow$ KPROS & -0.078 & -0.090 & 0.173 & 0.452 \\
H3b: OUT $\rightarrow$ KPROS & -0.037 & -0.020 & 0.065 & 0.581 \\
H4b: DIVERS $\rightarrow$ KPROS & -0.245 & -0.276 & 0.109 & 2.24 \\
\hline
\end{tabular}

\section{Pengujian dan Pembahasan $\mathrm{H}$ ipotesis $\mathrm{H} 4 \mathrm{a}$ dan $\mathrm{H} \mathbf{4 b}$}

Untuk $\mathrm{H} 4 \mathrm{a}$, diprediksikan bahwa diversity memiliki pengaruh positif terhadap keadilan prosedural untuk manajer dengan tingkat ketidakpastian tugas tinggi. Berdasarkan pengolahan data yang diperoleh dan disajikan dalam Tabel 5, diver sitymemiliki pengaruh negatif dan tidak signifikan terhadap keadilan prosedural di tingkat ketidakpastian tugas tinggi. Argumen tersebut didukung dengan nilai original sampel sebesar -0.144 dan t-statistik sebesar 1.14, maka dapat disimpulkan bahwa $\mathrm{H} 4 \mathrm{a}$ ditolak.

Hasil penelitian ini tidak dapat mendukung penelitian sebelumnya yang dilakukan olehHartmann dan Slapnicar (2012) yang melaporkan pengaruh yang kuat dan signifikan antara diversity dan keadilan prosedural di tingkat ketidakpastian tugas yang tinggi. Namun demikian, M oers (2005) dalam penelitiannya menemukan fakta bahwa penggunaan dimensi pengukuran kinerja yang beragam (diverse performance measures) mengarah pada penilaian kinerja yang kurang ketat dan tegas, sehingga dapat membuat hasil dan bias dari pengukuran menjadi kurang konsisten. Implikasinya adalah, bahwa peningkatan penggunaan pengukuran kinerja yang beragam dal am evaluasi kinerja dapat mengakibatkan situasi yang lebih kompleks, karena atasan akan mengal ami kesulitan dalam menimbang dan membedakan pengukuran kinerja berbeda yang akan digunakan, yang pada akhirnya akan menyebabkan masalah dalam pembuatan keputusan dan penentuan salary atau bonus untuk bawahan.

Untuk hipotesis $\mathrm{H} 4 \mathrm{~b}$, diprediksikan bahwa hubungan diversity terhadap persepsi keadilan tidak dipengaruhi oleh toleransi terhadap ambiguitas. Hasil pengujian pada tingkat toleransi ambiguitas tinggi menunjukkan nilai original sampel sebesar -0.169 dengan t-statistik 1.27.Adapun untuk tingkat toleransi ambi- 
guitas yang rendah, nilai original sampel adalah-0.245 dan t-statistik sebesar 2.24 (lihat Tabel $7 \&$ 8), sehingga dapat disimpulkan bahwa H4b ditolak.

Temuan ini tidak dapat mendukung penelitian sebelumnya yang dilakukan ol eh Hartmann dan Slapnicar (2012) yang melaporkan hubungan yang kuat dan signifikan antara diversity dan keadilan prosedural tanpa dipengaruhi toleransi terhadap ambiguitas. Namun Hartmann (2005) menemukan fakta bahwa manajer dengan toleransi terhadap ambiguitasrendahmungkin di satu sisi mempertimbangkan diverse metric sebagai kurang adil, karena adanya preferensi gambaran kinerja yang hitam-putih. Sebaliknya, Hartmann dan Slapnicar (2012) berpendapat bahwa high diverse metric dianggap dapat memperluas informasi seperti yang dicari oleh manajer dengan toleransi ambiguitas rendah. Adanya tarik menarik teori dalam penelitian yang dilakukan ol eh Hartmann (2005) serta Hartmann dan Slapnicar (2012) tersebut dapat menjadi penyebab utama adanya perbedaan hasil pada penelitian ini.

Dapat disimpulkan bahwa dalam proses evaluasi kinerja, atasan dapat memilih apakah mereka akan menggunakan pengukuran kinerja yang beragam (high diverse metric) atau satu jenis pengukuran saja (low diverse metric). Namun demikian, bawahan yang memiliki tingkat toleransi rendah terhadap ambiguitas mungkin saja berpendapat bahwa high diverse metric dapat mengakibatkan pengukuran kinerja terhadap mer eka menjadi kurang adil, dikarenakan adanya informasi yang beragam, yang menjadi pertimbangan atasan untuk melakukan peniIaian dalam evaluasi kinerja. Dengan demikian, permintaan bawahan akan pengukuran kinerjaberdasarkan low diverse metric mungkin akan meningkat, yang pada akhirnya dapat mengarah pada peningkatan persepsi keadilan.

\section{SIMPULAN, KETERBATASAN DAN SARAN}

\section{Simpulan}

Penelitian ini mencoba untuk mengkonfirmasi kembali bagaimana karakteristik evaluasi kinerja berhubungan dengan persepsi keadilan manajer.Memang, penelitian tentang keadilan prosedural sudah cukup banyak dilakukan.Namun demikian, pengetahuan tentang asal-usul keadilan prosedural, maupun karakteristik yang dapat meningkatkan persepsi tersebut masih terbilang jarang.

Secara keseluruhan, analisis dalam penelitian ini memberikan dukungan terhadap rel evansi dari variabel evaluasi kinerja yang dieksplorasi untuk persepsi keadilan. Dari empat el emen evaluasi kinerja yang diujikan, dapat dikatakan bahwa hanya voi ce yang memiliki efek yang kuat dan bersifat universal, namun efeknya lebih kuat untuk manajer dengan ketidakpastian tugas dan toleransi terhadap ambiguitasyang tinggi. Hal ini mengimplikasikan bahwa manajer, baik yang berada pada situasi ketidakpastian tugas maupun toleransi ambiguitas yang tinggi, tidak akan mentolerir adanya lack of voice, sehingga mereka membutuhkan pendapat dan suaranya tetap di pertimbangkan dalam proses evaluasi kinerja maupun pembuatan keputusan.

Efek formalitas dalam evaluasi kinerja, voice dan diversity pengukuran kinerja secara signifikan berbeda antara sub-grup ketidakpastian tugas dan tol eransi ambiguitas rendah dan tinggi. Formalitas hanya memiliki hubungan positif terhadap keadilan prosedural untuk manajer dengan ketidakpastian tugas rendah. Sehubungan dengan kriteria keadilan normatif (Leventhal, 1980), hal ini dapat diinterpretasikan dalam bentuk peningkatan konsistensi. Namun demikian, konsistensi tidak selalu terlihat penting, karena peningkatan formalitas dianggap tidak berkontribusi terhadap keadilan untuk manajer untuk dengan tingkat ketidakpastian tugas yang lebih, sehingga dimungkinkan pengukuran usaha terhadap mereka menjadi kurang akurat. 
Untuk konstrukoutcomemeasures, hasil pengujian menunjukkan bahwa ketidakpastian tugas dan toleransi terhadap ambiguitas dapat memoderasi keadilan prosedural.Pada tingkat ketidakpastian tugas dan toleransi ambiguitas yang tinggi, manajer akan cenderung mengharapkan pengukuran kinerja yang dilakukan terhadap mereka lebih berdasarkan pada usaha (effort), bukan berdasarkan hasil (outcome),karena hasil pekerjaan terkadang tidak dapat merefleksikan usaha mereka yang sesungguhnya sehingga pengukuran kinerja menjadi bias dan tidak akurat, yang pada akhirnya dapat mengakibatkan persepsi manajer terhadap keadilan prosedural menjadi rendah.

Diversitydalam pengukuran kinerja berpengaruh negatif dan tidak signifikan terhadap keadilan prosedural untuk manajer dengan ketidakpastian tugas tinggi, namun signifikan di tingkat toleransi terhadap ambiguitas rendah. Adanya per bedaan hasil penelitian antara M oers (2005), Hartmann (2005) dan Hartmann dan Slapnicar (2012) dan penelitian ini mengenai penggunaan pengukuran kinerja beragam dapat mengarah pada kesimpulan bahwa pengaruh diversity terhadap keadilan prosedural belum dapat dikatakan konsisten

\section{Keterbatasan}

Dalam penelitian ini, fokus sampel penelitian adalah middle managers, sehingga untuk tingkatan manajer yang lebih tinggi (upper-level), kemungkinan besar dibutuhkan interpretasi ulang yang lebih mendalam.Namun demikian, penelitian ini memiliki kemampuan generalisasi yang cukup baik, mengingat karakteristik dari organisasi yang dipilih sebagai sampel tidak harus bersifat spesifik.

Untuk hasil pengujian hi potesis, meskipun hasil dan temuan dalam penelitian ini secara garis besar dapat didukung oleh teori yang kuat, namun baik dalam penelitian Hartmann dan Slapnicar (2012) maupun dalam penelitian Ianjutan ini, hubungan formalitas $(\mathrm{H} 1 \mathrm{~b})$ dan pengaruh outcome measures $(\mathrm{H} 3 \mathrm{~b})$ terhadap keadilan prosedural untuk manajer dengan tingkat toleransi ambiguitas rendah tidak dapat dikonfirmasi dengan teori pendukung yang kuat, sehubungan dengan temuan yang bertolak-belakang dengan formula dan pengembangan teori yang diprediksikan. Hubungan formalitas dan pengaruh outcome measures terhadap keadilan prosedural justru positif dan signifikan untuk manajer dengan tingkat toleransi ambiguitas yang tinggi.

\section{Saran}

Berdasarkan keterbatasan penelitian yang sebelumnya dibahas, maka hal tersebut diharapkan dapat memberi peluang bagi penelitian akan datang untuk mengembangkan el emen lain dari eval uasi kinerja, yaitu karakteristik proses dan metrik yang berbeda dengan mempertimbangkan variabel dan indikator-indikator lain, dan bagaimana varian tersebut dipengaruhi oleh peran ketidakpastian manajemen dalam konteks yang berbeda, untuk kelompok tertentu yang lain di luar penelitian ini. Selain itu, studi lebih lanjut terhadap objek berbeda, misal nya, pada organisasi-organisasi non-profit, perusahaan di bidang jasa, BUMN, maupun bidang lain diluar manufaktur dengan skala yang lebih besar, akan sangat direkomendasikan.

\section{DAFTAR PUSTAKA}

Bagozzi, R.P., 1994. Structural equation models in marketing research:basic principles. In: Bagozzi (Ed.), Principles of Marketing Research.Blackwell Business.

Budner, S., 1962. Intolerance for ambiguity as a personal variable. J ournal of personality $30,29-50$. 
Choudhury, N., 1986. Responsibility accounting and controllability. Accounting and Business Research (Summer), 189-198.

De Cremer, D., Sedikies, C., 2005. Self-uncertainty and responsiveness to procedural justice. J ournal of Experimental Social Psychology 41, 157-173.

Diekmann, K.A., Barsness, Z.I ., Sondak, H., 2004. Uncertainty, fairness perceptions and job satisfaction: a field study. Social J ustice Research 17,237-255.

Eisenhardt, K.M., 1985. Control: organizational and economic approaches. Management Science 31 (2), 134-149.

Folger, R., Greenberg, J ., 1985. Procedural J ustice: an interpretative analysis of personnel systems. Research in Personnel and H uman resource M anagement 3, 141-183.

Folger, R., Konovsky, M.A., 1989. Effects of procedural and distributivejustice on reactions to pay raise decicions. Academy of Management J ournal 32, 115130.

Ghozali, Imam., 2006. Structural Equation Modelling: Metode Alternatif Partial Least Square: Edisi 2. Universitas Diponegoro

Hartmann, F.G.H., 2000. The appropriateness of RAPM; toward the further development of theory. Accounting, Organizations and Society 25, 451-482.

Hartmann, F.G.H., 2005. The effect of tol er ance for ambiguity and uncertainty on the appropriateness of accounting performance measures. ABACUS 41 (3), 241-264.

Hartmann, F., Slapnicar, S., 2012. The perceived fairness of performance evaluation: The role of uncertainty. Management Accounting Research 23, 17-33.

Itnerr, C.D., Larcker, D.F. Randall, T., 2003. Performance implications of strategic performance measurement in financial service firms. Accounting, Organizations and Society 28 (7-8), 715-741.

Landy, F.J ., 1978.Psychology and Work Behavior, vol. 63.Brooks/Cole.

Lau, C.M., Moser, A., 2008. Behavioral effect of nonfinancial performance measures: the role of procedural fairness. Behavioral Research in Accounting 20, 55-71.

Leventhal, G.S., 1976. Fairness in social relationships. I n: Thi baut, J .W., Spence, J .T., Carson, R.C. (E ds.), Contemporary Topics in Social Psychology. General Learning Press, Morristown, NJ , pp. 211-239.

Leventhal, G.S., Karuza, J ., Fry, W.R., 1980. Beyond fairness: a theory of allocation preferences. In: Mikula, G. (Ed.), J ustice and Social I nteraction. SpringerVerlag, New York, pp. 167-218.

Lind, E.A., van den Bos, K., 2002. When fairness works: toward a general theory of uncertainty management. Research in Organizational Behaviour 24, 181223.

MacDonald, A.P., 1970. Revised scal e for ambiguity tolerance: reliability and validity. Psychological Reports 26 (6), 791-798.

Marginson, D., Ogden, S., 2005. Coping with ambiguity through the budget: the positive effects of budgetary targets on managers' budgeting behaviours. Accounting, Organizations and Society 30 (5), 435-456.

Merchant, K.A., 1989. Rewarding Results: Motivating Profit Center Managers. Harvard Business School Press, Boston, MA.

Moers, F., 2005. Discretion and bias in performance evaluation: the impact of diversity and subjectivity. Accounting, Organizations and Society 30, 67-80.

Norton, R.W., 1975. Measurement of ambiguity tolerance. J ournal of Per sonal ity Assessment 39 (6), 607-619.

Ouchi, W., 1979. A conceptual framework for the design of organization control mechanisms. Management Science 25, 833-848. 
Karakteristik Shields, J., Shields, M., 1998. Antecedents of participative budgeting. Accounting, Proses.... Organizations and Society 23, 49-76.

Thibault, J ., Walker, L., 1975. Procedural J ustice: A Psychological Analysis. Erlbaum, Hillsdale, New York.

Vandenbosch, M.B., 1996. Conûrmatory compositional approaches to the devel opment of product spaces. European J ournal of Marketing 30, 23-46.

Werts, C.E., Linn, R.L., dan J oreskog, K.G.(1974). I ntraclass reliability estimates: Testing structural

assumptions. Educational and Psychological Measurement, 34(1), 25-33.

Withey, M., Daft, R.L., William, H.C., 1983. Measures of Perrow's work unit technol ogy: an empirical assessment and a new scale. Academy of Management J ournal 26 (1), 45-63 